\title{
Studi Tentang Pembuatan Lampion Berbahan Limbah Goni Rami Pada Mata Pelajaran Prakarya Siswa Kelas VIII SMP Negeri 2 Takengon T.A 2020/2021
}

\section{A Study on Making Lanterns Made from Hemp Sack Waste in Crafting Subjects for Class VIII Students of SMP Negeri 2 Takengon T.A 2020/2021}

\author{
Pinte Ara* \& Azmi \\ Program Studi Pendidikan Seni Rupa, Jurusan Seni Rupa, Fakultas Bahasa Dan Seni \\ Universitas Negeri Medan
}

Diterima: 01 Juni 2021 Direview: 01 Juni 2021; Disetujui: 08 Agustus 2021

*Coresponding Email: pinteara@gmail.com

\begin{abstract}
Abstrak
Penelitian ini bertujuan untuk Untuk mengetahui bagaimana kemampuan siswa kelas viii smp negeri 2 takengon dalam bereksperimen dengan limbah goni rami sebagai bahan membuat kerajinan tangan lampion. penelitian ini menggunakan metode penelitian deskriptif kualitatif. teknik pengumpulan data yang digunakan adalah observasi, wawancara dan dokumentasi. populasi penelitian ini berjumlah 180 siswa. sampel yang digunakan terdiri dari 5 karya dengan menggunakan teknik sampling bertujuan yaitu dilakukan dengan cara mengambil sunjek bukan diatas rata-rata, random atau daerah, tetapi didasarkan adanya tujuan tertentu. indikator penilaian yang diteliti dalam penelitian ini warna, kesatuan dan nilai fungsional. Hasil penelitian Studi Tentang Pembuatan Lampion Berbahan Limbah Goni Rami Pada Mata Pelajaran Prakarya Siswa Kelas VIII SMP Negeri 2 Takengon Tahun Ajaran 2020/2021 menunjukkan secara keseluruhan memperoleh nilai Baik (B). Nilai Baik Tersebut dilihat dari hasil karya siswa yang menggunakan tiga indikator penilaian dalam pembuatan lampion berbahan limbah goni rami dan dinilai oleh tiga tim penilai/ validator.
\end{abstract}

Kata kunci: Lampion; Limbah; Goni Rami.

\begin{abstract}
This study aims to determine how the ability of grade VIII students of SMP Negeri 2 Takengon in experimenting with jute sack waste as a material for making lantern handicrafts. This research uses descriptive qualitative research methods. The data collection techniques used were observation, interview and documentation. The population of this research is 180 students. The sample used consisted of five works using a sampling technique aimed at taking the subject not above average, random or regional, but based on a specific purpose. The assessment indicators examined in this study were color, unity and functional value. The results of the study on the manufacture of lanterns made from hemp sack waste in craft subjects for Class VIII students of SMP Negeri 2 Takengon in the academic year of 2020/2021 showed that overall they received a good score (B). This good value is seen from the work of students who use three assessment indicators in making lanterns made from jute sack waste and are assessed by three teams of assessors / validators.
\end{abstract}

Key words: Lanterns; Waste; Hemp Sacks.

How to Cite: Ara, P. \& Azmi (2021). Studi Tentang Pembuatan Lampion Berbahan Limbah Goni Rami Pada Mata Pelajaran Prakarya Siswa Kelas VIII SMP Negeri 2 Takengon T.A 2020/2021. Journal of Education, Humaniora and Social Sciences (JEHSS). 4(2): 821-829. 


\section{PENDAHULUAN}

Salah satu pokok bahasan Seni Rupa yang diberikan di sekolah adalah mata pelajaran Prakarya. Sekolah Menengah Pertama (SMP) Negeri 2 Takengon salah satu sekolah yang menerapkan mata pelajaran Prakarya. Mata pelajaran prakarya terdiri dari aspek Kerajinan, Rekayasa, Budidaya dan Pengolahan. Dasar pembelajaran Prakarya berbasis budaya ini di harapkan dapat menumbuhkan nilai kearifan lokal sehingga tumbuh kemandirian kewirausahaan, sekaligus melestarikan potensi dan nilai-nilai kearifan lokal. (Sinaga \& Triyanto, 2019).

Berdasarkan pengamatan awal yang dilakukan Observasi di SMP Negeri 2 Takengon, Kurangnya minat siswa akan bahan sederhana untuk membuat kerajinan tangan, siswa berpatokan pada bahan-bahan Baru (Konvensional) sebagai bahan membuat kerajinan, pembelajaran prakarya kerajinan tangan hanya berdasarkan teori, kurang melakukan praktik dalam pengaplikasian teorinya.(Utami dkk, 2020). Pengetahuan dalam proses pembuatan kerajinan tangan sangat penting diketahui karena akan mempengaruhi hasil karya kerajinan tangan. Kurangnya pengetahuan proses pembuatan karya siswa jadi tidak semangat dalam membuat kerajinan tangan, karna karya yang di hasilkan pun kurang maksimal, Siswa mengalami banyak kesulitan mulai dari mencari ide bagaimana cara menciptakan karya kerajinan yang menarik, unik dan kreatif. (Tanjung \& Munthe, 2020)

Hal terpenting lainnya selain keaktifitasan siswa dalam mencari sumber materi ialah peran guru dalam membimbing dan memberikan informasi sebaik-baiknya dalam mengajar pelajaran prakarya. Tetapi dikarenakan Minimnya jumlah guru yang berada di daerah membuat setiap guru kerap mengajar tak sesuai dengan bidang studi yang mereka ajarkan. Sehingga pembelajaran prakarya hanya berupa teori yang terdapat pada buku paket saja. Siswa kurang mengenalkan media Kerajinan tangan yang lainnya dalam berkarya. Padahal media yang dapat digunakan dalam membuat kerajinan tangan sangat luas, dan tidak hanya berpatokan pada media yang sudah sering di gunakan seperti limbah kertas, limbah koran, limbah botol air mineral, limbah galon air mineral, limbah kardus, limbah kaleng dan lain sebagainya.

Siswa seharusnya dapat memanfaatkan media yang ada di sekitar lingkungannya misalnya memanfaatkan limbah goni rami sebagai media kerajinan tangan dengan menghasikan suatu produk lampion. Lampion berbahan limbah goni rami bisa di jadikan untuk aksesoris ruangan atau pelengkap keindahan interior, lampu tidur, lampu hias dengan barbagai jenis dan bentuk. Lampion berbahan limbah goni rami ini merupakan salah satu kerajinan dengan memanfaatkan bahan alam yang saat ini masih sangat jarang digunakan sebagai bahan kerajinan terkhususnya di Takengon Aceh Tengah. Hal ini menunjukkan bahwa rasa ingin tahu siswa terhadap kerajinan tangan dengan bahan-bahan sederhana masih sangat rendah, Kerajinan tangan berbahan limbah goni rami terlihat unik karena memiliki tektur mudah dipintal/diolah, karakteristiknya Panjang kekuatannya besar tahan lama dan warna yang khas dari limbah goni rami tersebut. Selain itu pemanfaatan limbah goni rami dalam proses pembelajaran dapat mengasah kreativitas siswa dan juga dapat menumbuhkan kesadaran siswa membuat kerajian tidak hanya dari bahan-bahan baru (konvensional) tetapi bisa dengan bahan limbah yang dapat bernilai jual.

Pembahasan terkait pernah dilakukan oleh Sanjaya (2016) dengan judul pembahasan "Fungsi dan Makna Penyambutan Hari Raya Imlek Pada Masyarakat Etnis Tionghoa Di Kota Bandar Lampung tahun 2016". Tujuan penelitian ini adalah untuk menunjukkan bagaimana fungsi dan makna penyambutan Hari Raya Imlek Pada Masyarakat Etnis Tionghoa. Hasil penelitian ini menunjukkan adat dan budaya dari dari etnis Tionghoa, dimana setiap perayaan Imlek mereka selalu memasang pernak-pernik khas salah satunya lampion.

Selanjutnya Rinaldy (2021) dengan judul "Studi Bentuk Kerajinan Bahan Karung Goni Karya Sukirno Di Bengkel Keramas Medan Sunggal Kelurahan Tanjung Rejo". Dalam penelitian ini menunjukkan bagaimana teknik, bentuk yang di gunakan serta dapat mengoptimalkan kreativitas dalam menggunakan bahan karung goni yang bernilai estetis dan bernilai jual tinggi.

Adapun tujuan dari penelitian ini yaitu agar siswa tidak berpatokan pada bahan-bahan baru (konvensional) sebagai bahan kerajinan serta untuk mengetahui Bagaimana kemampuan siswa 
Kelas VIII SMP Negeri 2 Takengon dalam bereksperimen dengan limbah goni rami sebagai bahan membuat kerajinan tangan lampion.

\section{METODE PENELITIAN}

Togarma (1998) metodologi ialah ilmu atau studi tentang berbagai metode, juga dapat di sebut sebagai perangkat metode yang digunakan dalam suatu pekerjaan. Sugiyono (2011) menjelaskan penggunaan metode yang tepat akan memberikan hasil yang baik akan tercapai tujuan untuk menjawab hipotesis yang telah dirumuskan. Oleh karena itu, metode penelitian memegang peranan yang sangat penting dalam sebuah penelitian.

Hal ini sejalan dengan metode penelitian yang digunakan oleh peneliti dalam pengumpulan data menggunakan metode kualitatif dengan pendekatan studi deskriptif, sebagaimana yang di tetapkan oleh Sugiyono (2011) adalah metode kualitatif untuk mendapatkan data yang mendalam, suatu data yang mengandung makna. Metode secara signifikan dengan mempengaruhi makna. Metode secara signifikan dapat mempengaruhi subtansi penelitian. Artinya bahwa metode kualitatif menyajikan secara langsung hakikat hubungan antara peneliti dan informan.

Sugito (2018) populasi adalah keseluruhan subjek dan objek yang diteliti dengan segenap karakteristiknya. Arikunto (2010) populasi adalah keseluruhan subjek penelitian apabila seseorang ingin meneliti semua elemen yang ada dalam wilayah penelitian, maka penelitiannya merupakan penelitian populasi. Studi atau penelitiannya juga disebut populasi atau studi sensus. Berdasarkan pendapat diatas populasi dalam penelitian ini adalah jumlah dari keseluruhan pada objek penelitian. Adapun jumlah ruangan kelas VIII di SMP Negeri 2 Takengon ada 6 ruangan dengan masing-masing siswa berjumlah 30 siswa, jadi total keseluruhan siswa kelas VIII di SMP Negeri 2 Takengon berjumlah 180 siswa. pada saat pandemi Covid-19 siswa yang awalnya sekelas berjumlah 30 siswa dibagi menjadi dua, maka jumlah populasi penelitian ini yaitu 15 karya kerajinan tangan siswa.

Sampel adalah sebagai populasi yang diteliti atau wakil dari populasi (Sugito, 2018). Sugiyono (2011) sampel adalah bagian dari jumlah dan karakteristik yang dimiliki oleh populasi. Sedangkan menurut Sudjana (2005) adapun sebagian yang diambil dari populasi disebut sampel. Dari pendapat diatas dapat disimpulkan bahwa sampel adalah sebagian dari jumlah populasi atau yang mewakili dari populasi yang akan diteliti. Peneliti menggunakan sampling bertujuan dilakukan dengan cara mengambil subjek bukan didasarkan atas rata-rata, random atau daerah, tetapi didasarkan atas adanya tujuan tertentu. Alasan peneliti menggunakan teknik sampling bertujuan dikarenakan Faktor Bias dan pada saat ini situasi pandemi Covid-19 yang berdampak pada jumlah siswa yang belajar tatap muka yang awalnya terdiri dari 30 siswa pada satu ruangan tetapi dibagi dua menjadi dua sehingga satu ruangan/ kelas menjadi 15 siswa maka dari itu peneliti menggunakan teknik sampling bertujuan. Sampel dari peneliti ini yakni kelas VII ${ }^{2}$ SMP Negeri 2 Takengon dengan jumlah siswa 15 orang tetapi sampel yang akan dibahas sebanyak 5 karya.

Tabel 1. Daftar Nama Siswa

\begin{tabular}{ccc}
\hline No. & Nama Siswa & Karya \\
\hline 1. & Alfi Arangga & Karya 1 \\
\hline 2. & Fahmi Adriansyah & Karya 2 \\
\hline 3. & Azmi Ariga & Karya 3 \\
\hline 4. & Kaisya Nabila & Karya 4 \\
\hline 5. & Tommy Chen & Karya 5 \\
\hline
\end{tabular}

Selanjutnya instrumen penelitian yaitu alat bantu yang dipilih dan digunakan oleh peneliti dalam melakukan kegiatannya untuk mengumpulkan data agar kegiatan tersebut menjadi sistematis dan dipermudah. Instrumen dan alat yang digunakan dalam penelitian ini terdiri dari buku catatan, kamera dan daftar pertanyaan.

Adapun teknik analis data terbagi dua macam yaitu analisis non statistik dan analisis statistik. Analisis non statistik adalah cara membahas hasil dan menarik kesimpulan penelitian 
berupa gambaran tentang sesuatu gejala atau perkembangan pada saat ini dengan data kualitatif. Analisis statistik adalah cara membahas hasil dan menarik kesimpulan penelitian dengan menggunakan angka-angka (Sugito, 2018).

Teknik analisis data adalah suatu yang digunakan untuk menentukan suatu penjelasan halhal yang ada di penelitian adalah deskriptif kualitatif. Dari data yang akan diteliti kemudian dinilai dari tim penilaian, berdasarkan nilai tersebut maka penulis menganalisis dan mengkaji untuk mendapat hasil yang sesuai dengan penelitian dan untuk membuat suatu kesimpulan.

Langkah-langkah yang dilakukan untuk menganalisis data adalah sebagai berikut, Setelah data terkumul semua, tabel data sesuai variabel yang diteliti yaitu: kesatuan, keselarasan, keseimbangan dan nilai fungsional. Berdasarkan skor yang diperoleh pada masing-masing variabel dapat dikategorikan menjadi 4 kelompok.

Tabel 2. Rentang Penilaian Karya

\begin{tabular}{ccccc}
\hline No. & Rentang Nilai & Kategori & Keterangan & Skor \\
\hline 1. & $86-100$ & Sangat Baik & A & 4 \\
\hline 2. & $71-85$ & Baik & B & 3 \\
\hline 3. & $56-70$ & Cukup & C & 2 \\
\hline 4. & $0-55$ & Kurang & D & 1 \\
\hline
\end{tabular}

Sumber: SMP Negeri 2 Takengon

Berdasarkan penilaian tersebut dapat digolongkan siswa yang berhasil dalam pembuatan lampion berbahan limbah goni berdasarkan nilai-nilai estetika adalah siswa yang dapat memperoleh nilai dengan kategori sangat baik dan baik. Sedangkan nilai dengan kategori cukup, kurang dan sangat kurang merupakan siswa yang belum dapat membuat berdasarkan nilainila estetika, karena nilai yang kurang belum dapat memenuhi aspek penilaian yang telah ditentukan.

Aspek penilaian dilakukan oleh tiga penilai, yaitu :

1. Irwansyah, S.Pd. Nip. 198104202009041005 (Guru Bidang Studi Seni Budaya (Seni Rupa) SMA Negeri 1 Takengon)

2. Dra. T. Sri Aminah. Nip. 196611181993032002 (Guru Bidang Studi Prakarya SMP Negeri 29 Medan)

3. Rahendra salam S.sos (Praktisi seni)

Tabel 3. Indikator Penilaian Karya

\begin{tabular}{|c|c|c|c|c|c|c|}
\hline No & Indikator & $\begin{array}{c}\text { Bob } \\
\text { ot }\end{array}$ & Deskriptor & $\begin{array}{l}\text { Rentan } \\
\text { g Skor }\end{array}$ & Skor & Nilai \\
\hline \multirow[t]{3}{*}{1.} & \multirow[t]{3}{*}{ Warna } & \multirow[t]{3}{*}{35} & 1. Menghasilkan warna yang unik & $2-15$ & & \multirow{9}{*}{$\begin{array}{l}\text { Rentang } \\
\text { penilaia } \\
\text { n: } 86- \\
100=A \\
\text { (sangat } \\
\text { baik) } \\
71-85= \\
\text { B (baik) } \\
56-70= \\
\text { C } \\
\text { (cukup) } \\
0-55=\text { D } \\
\text { (kurang } \\
\text { ) }\end{array}$} \\
\hline & & & $\begin{array}{l}\text { 2. Visualisasi warna tampak rapi serasi dengan } \\
\text { bentuk keseluruhannya }\end{array}$ & $2-10$ & & \\
\hline & & & 3. Teknik pewarnaan dilakukan dengan tepat & $2-10$ & & \\
\hline \multirow[t]{3}{*}{2.} & \multirow[t]{3}{*}{ Kesatuan } & \multirow[t]{3}{*}{35} & 1. Kekokohan karya & $2-15$ & & \\
\hline & & & $\begin{array}{l}\text { 2. Pemilihan bentuk yang menghasilkan efek } \\
\text { tertentu }\end{array}$ & $2-10$ & & \\
\hline & & & $\begin{array}{l}\text { 3. Susunan penempelan tali rami tidak terlalu } \\
\text { jarang dan rapat }\end{array}$ & $2-10$ & & \\
\hline \multirow[t]{3}{*}{3.} & \multirow[t]{3}{*}{$\begin{array}{l}\text { Nilai } \\
\text { Fungsional }\end{array}$} & \multirow[t]{3}{*}{30} & $\begin{array}{l}\text { 1. Karya dibuat untuk memenuhi kebutuhan } \\
\text { masyarakat }\end{array}$ & $2-10$ & & \\
\hline & & & $\begin{array}{l}\text { 2. Karya yang dibuat dapat dijadikan aksesoris } \\
\text { ruangan atau pelengkap keindahan interior, } \\
\text { lampu tidur, lampu hias dengan berbagai } \\
\text { jenis dan bentuk }\end{array}$ & $2-10$ & & \\
\hline & & & 3. Karya lampion tahan lama & $1-10$ & & \\
\hline & Jumlah & 100 & Jumlah Skor & & & \\
\hline
\end{tabular}

\section{HASIL DAN PEMBAHASAN}

\section{Lampion}


Secara kebahasaan menurut Kamus Besar Bahasa Indonesia, lampion itu artinya adalah lentera yang terbuat dari kertas (penerangannya dengan lilin), dipakai pada perayaan atau pesta. Di Indonesia, lampion biasa disebut dengan deng long.

Syamsiar dalam Tjoa (2017) menyatakan bahwa : Lampion telah menjadi tradisi bagi orang Tionghoa sebagai simbol kebahagiaan, yang dipasang untuk eventevent kegembiraan berwarna merah, dan lampion putih terbuat dari rangka bambu untuk simbol bela sungkawa. Dalam perkembangannya, lampion digambari dan dihiasi ornamen-ornamen macam-macam, dan hurufhuruf kaligrafi. Lampion ada yang terbuat dari kertas, kain, kulit binatang, dan dari bordiranbordiran kain sutra dan lain-lain. Lampion bagi orang Tionghoa tidak saja sebagai lampu penerangan atau lentra, tapi sudah menjadi simbol.

Bentuk lampion pada umumnya mengandung unsur-unsur rupa yang terpadu, sebagai kesatuan yang harmonis, seimbang, sebanding, dan berirama sehingga bernilai estetis.Makna simbolis yang terkandung di dalamnya umumnya menyampaikan pesan nilai-nilai keagamaan, dan kritik sosial kemasyarakatan (Syamsiar, 2016). Macam-macam lampion terdiri dari lampion oriental, lampion terbang, lampion apung, lentera lilin, lampion Jepang dan lampion Vietnam (Luwin, 2019).

Warna. Warna kesan yang diperoleh mata dari cahaya yang di pantulkan benda-benda yang dikenainya; corak rupa seperti merah, biru, hijau, dan lain-lain. Peranan warna sangat dominan pada karya seni rupa, hal ini dapat dikaitkan dengan upaya menyatakan gerak, jarak tegangan (tension), deskripsi alam (naturalisme), ruang, bentu, ekspresi atau makna simbolik dan justru dalam kaitan yang beraneka ragam ini kita akan melihat betapa kedudukan warna dalam seni lukis (rupa) (Susanto, 2002). Warna adalah gelombang cahaya dengan frekuensi yang dapat memengaruhi penglihatan kita. Warna memiliki tiga dimensi dasar yaitu hue, nilai (value), dan nilai intensitas (intensity). Hue adalah gelombang khusus dalam spektrum dan warna tertentu. Misalnya Spekrum warna merah disebut hue merah, Nilai (value) adalah nuansa yang terdapat pada warna, seperti nuansa verah atau gelap, sedangkan intensitas adalah kemurnian dari hue warna (Bahari, 2017). Dapat disimpulkan bahwa warna berarti pantulan tertentu dari cahaya yang dipengaruhi oleh pigmen yang terdapat di permukaan benda, Setiap warna mampu memberikan kesan dan identitas tertentu sesuai kondisi sosial pengamatnya. Kesatuan atau unity merupakan salah satu prinsip yang menekankan pada keselarasan dari unsur-unsur yang disusun, baik dalam wujudnya maupun kaitannya dengan ide yang melandasinya (Wong, 1986). Kesatuan adalah kohesi, konsistensi, ketunggalan atau keutuhan, yang merupakan isi pokok dari komposisi (Dharsono, 2017). Dapat disimpulkan bahwa keselarasan adalah visualisasi susunan teratur dari keseluruhan bagian-bagian yang saling terkait dengan baik langsung maupun tidak langsung.

Keseimbangan. Keseimbangan atau balance merupakan prinsip dalam komposisi yang menghindari kesan berat sebelah atas suatu bidang atau ruang yang diisi dengan usur-unsur rupa (Wong, 1986). Keseimbangan adalah hubungan antara kekuatan-kekuatan yang bertentangan. Secara umum keseimbangan terbagu dua tipe yaitu simetris dan asimetris. Keseimbangan simetris dapat digambarkan sebagai keseimbangan sama "berat" yang ditempatkan pada ii yang ama dari titik tumpu terpusat, dapat disebut sebagai keseimbangan formal. Keseimbangan asimetris juga disebut keseimbangan informal lebih kompleks dan sulit untuk membayangkannya (Sembiring, 2014). Dapat disimpulkan keseimbangan adalah penempatan unsur rupa dalam satu bidang baik secara beraturan maupun acak yang menekankan aspek keseimbangan komposisi unsur-unsur rupa didalamnya, keseimbangan dapat mencapai melalui penyusunan unsur rupa yang simetris atau dengan peletakan bentuk yang asimetris.

Nilai Fungsional. Nilai fungsional merupakan nilai yang berkaitan langsung dengan fungsi yang diberikan oleh produk atau layanan kepada konsumen.

\section{Data Hasil Validator}

Hasil penilaian terhadap pembuatan lampion berbahan limbah goni rami pada mata pelajaran prakarya siswa kelas VIII SMP Negeri 2 Takengon, maka dapat diperoleh data-data sebagai berikut: 
Tabel 4. Lembar Penilaian dari Penilai 1 (Irwansyah S.Pd)

\begin{tabular}{ccccccc}
\hline No. & Karya Lampion & \multicolumn{3}{c}{ Tim Penilai } & Jumlah & Ket \\
\cline { 3 - 5 } & & Warna & Kesatuan & $\begin{array}{c}\text { Nilai } \\
\text { Fungsional }\end{array}$ & & \\
\hline 1. & Karya 1 & 28 & 25 & 30 & 83 & B \\
\hline 2. & Karya 2 & 30 & 25 & 28 & 83 & B \\
\hline 3. & Karya 3 & 33 & 30 & 30 & 93 & A \\
\hline 4. & Karya 4 & 33 & 32 & 28 & 93 & A \\
\hline 5. & Karya 5 & 30 & 32 & 30 & 92 & A \\
\hline & Jumlah & 154 & 144 & 146 & 444 & \\
\hline & Rata-rata & 30,8 & 28,8 & 29,2 & 88,8 & \\
\hline
\end{tabular}

Dari data table 4, diperoleh penilaian dari lima karya oleh penilai 1, yaitu terdiri dari tiga karya lampion berbahan limbah goni rami memperoleh jumlah nilai 92-100 (Sangat Baik) dan sedangkan dua karya lampion berbahan limbah goni rami memperoleh jumlah nilai 83-85 (Baik).

Tabel 5. Lembar Penilaian dari Penilai 2 (Dra. T. Sri Aminah)

\begin{tabular}{ccccccc}
\hline No. & Karya Lampion & \multicolumn{3}{c}{ Tim Penilai } & Jumlah & Ket \\
\cline { 3 - 5 } & & Warna & Kesatuan & $\begin{array}{c}\text { Nilai } \\
\text { Fungsional }\end{array}$ & & \\
\hline 1. & Karya 1 & 30 & 34 & 29 & 93 & A \\
\hline 2. & Karya 2 & 25 & 31 & 30 & 86 & A \\
\hline 3. & Karya 3 & 32 & 22 & 28 & 82 & B \\
\hline 4. & Karya 4 & 25 & 28 & 25 & 78 & B \\
\hline 5. & Karya 5 & 28 & 26 & 25 & 79 & B \\
\hline & Jumlah & 140 & 141 & 137 & 418 & \\
\hline & Rata-rata & 28 & 28,2 & 27,4 & 83,6 & \\
\hline
\end{tabular}

Dari data tabel 5, diperoleh penilaian dari lima karya oleh penilai 2, yaitu terdiri dari dua karya lampion berbahan limbah goni rami memperoleh jumlah nilai 86-100 (Sangat Baik) dan sedangkan tiga karya lampion berbahan limbah goni rami memperoleh jumlah nilai 78-85 (Baik).

Tabel 6. Lembar Penilaian dari Penilai 3 (Rahendra Salam S.Sos)

\begin{tabular}{ccccccc}
\hline No. & Karya Lampion & \multicolumn{3}{c}{ Tim Penilai } & Jumlah & Ket \\
\cline { 3 - 5 } & & Warna & Kesatuan & $\begin{array}{c}\text { Nilai } \\
\text { Fungsional }\end{array}$ & & \\
\hline 1. & Karya 1 & 33 & 28 & 25 & 86 & A \\
\hline 2. & Karya 2 & 24 & 27 & 29 & 80 & B \\
\hline 3. & Karya 3 & 24 & 22 & 22 & 68 & C \\
\hline 4. & Karya 4 & 24 & 27 & 28 & 79 & B \\
\hline 5. & Karya 5 & 30 & 31 & 25 & 86 & A \\
\hline & Jumlah & 135 & 135 & 129 & 399 & \\
\hline & Rata-rata & 27 & 27 & 25,8 & 79,8 & \\
\hline
\end{tabular}

Dari data tabel 6, diperoleh penilaian dari lima karya oleh penilai 3, yaitu terdiri dari dua karya lampion berbahan limbah goni rami memperoleh jumlah nilai 86-100 (Sangat Baik), sedangkan dua karya lampion berbahan limbah goni rami memperoleh jumlah nilai 79-85 (Baik) dan 1 karya karya lampion berbahan limbah goni rami memperoleh jumlah nilai 68-70 (Cukup).

Tabel 7. Data Hasil Penggabungan Nilai dari 3 Tim Penilai

\begin{tabular}{|c|c|c|c|c|c|c|c|}
\hline \multirow[t]{2}{*}{ No. } & \multirow{2}{*}{$\begin{array}{c}\text { Karya } \\
\text { Lampion }\end{array}$} & \multicolumn{3}{|c|}{ Tim Penilai } & \multirow[t]{2}{*}{ Jumlah } & \multirow{2}{*}{$\begin{array}{l}\text { Rata-Rata } \\
(\Sigma N) / M\end{array}$} & \multirow[t]{2}{*}{ Ket } \\
\hline & & Penilai 1 & Penilai 2 & Penilai 3 & & & \\
\hline 1. & Karya 1 & 83 & 93 & 86 & 262 & 87 & $\mathrm{~A}$ \\
\hline 2. & Karya 2 & 83 & 86 & 80 & 249 & 83 & B \\
\hline
\end{tabular}


Vol 4, No. 2, November 2021: 821-829

\begin{tabular}{cccccccc}
\hline 3. & Karya 3 & 93 & 82 & 68 & 243 & 81 & $\mathrm{~B}$ \\
\hline 4. & Karya 4 & 93 & 78 & 79 & 250 & 83 & $\mathrm{~B}$ \\
\hline 5. & Karya 5 & 92 & 79 & 86 & 257 & 86 & $\mathrm{~A}$ \\
\hline & Jumlah & 444 & 418 & 399 & 1.261 & 420 & \\
\hline Rata-Rata & 89 & 84 & 80 & 252 & 84 & $\mathrm{~B}$ \\
\hline Keterangan & $\mathrm{A}$ & $\mathrm{B}$ & $\mathrm{B}$ & & \\
\hline
\end{tabular}

Berdasarkan data table 7, diperoleh nilai dari lima karya lampion berbahan goni rami dengan tiga tim penilai pada karya siswa SMP Negeri 2 Takengon memperoleh jumlah 420 dengan nilai rata-rata 84 (Baik). Adapun penilaian dari ketiga indikator yaitu, Warna pada karya memperoleh jumlah nilai 444 dengan nilai rata-rata 89 (Sangat Baik), kesatuan dengan jumlah nilai 418 dengan nilai rata-rata 84 (Baik) dan nilai fungsional dengan jumlah nilai 399 dengan nilai rata-rata 80 (Baik).

Dari data hasil analisis penelitian dapat dilihat tabel 7 dengan karya studi tentang pembuatan lampion berbahan limbah goni rami pada mata pelajaran prakarya siswa kelas VIII ${ }^{2}$ SMP Negeri 2 Takengon dengan indikator penilaian warna, kesatuan dan nilai fungsional:

Tabel 8. Hasil Penilaian Karya 1

\begin{tabular}{|c|c|c|c|c|c|c|}
\hline Karya Lampion & $\begin{array}{l}\text { Indikator } \\
\text { Penilaian }\end{array}$ & $\begin{array}{c}\text { Penilai } \\
1 \\
\end{array}$ & $\begin{array}{c}\text { Penilai } \\
2\end{array}$ & $\begin{array}{c}\text { Penilai } \\
3\end{array}$ & Jumlah & Ket \\
\hline & Warna & 28 & 24 & 33 & 85 & $\mathrm{~B}$ \\
\hline & Kesatuan & 29 & 34 & 28 & 91 & $\mathrm{~A}$ \\
\hline & Nilai Fungsional & 26 & 29 & 25 & 80 & $\mathrm{~B}$ \\
\hline & \multicolumn{4}{|c|}{ Jumlah } & 256 & \\
\hline & \multicolumn{4}{|c|}{ Rata-Rata } & 85 & B \\
\hline
\end{tabular}

Berdasarkan tabel 8, diperoleh hasil dari penilaian karya 1 dari indikator warna pada tim penilai satu memberi nilai 28 , tim penilai dua memberi nilai 24 dan tim penilai tiga memberi nilai 33 dengan jumlah keseluruhan nilai yaitu 85. Pada indikator penilaian kesatuan dengan tim penilai satu memberi nilai yaitu 29 , tim penilai dua memberi nilai 34 , dan tim penilai tiga memberi nilai 28 dengan jumlah nilai keseluruhan 91. Pada indikator penilaian nilai fungsional dengan tim penilai satu memberi nilai 26 , tim penilai dua memberi nilai 29 dan tim penilai tiga memberi nilai 25 dengan jumlah keseluruhan nilai 80. Dari hasil yang di dapatkan dengan jumlah keseluruhan diperoleh nilai 256 dengan nilai rata-rata 85.

Tabel 9. Hasil Penilaian Karya 2

\begin{tabular}{|c|c|c|c|c|c|c|}
\hline Karya Lampion & $\begin{array}{l}\text { Indikator } \\
\text { Penilaian }\end{array}$ & $\begin{array}{c}\text { Penilai } \\
1\end{array}$ & $\begin{array}{c}\text { Penilai } \\
2 \\
\end{array}$ & $\begin{array}{c}\text { Penilai } \\
3 \\
\end{array}$ & Jumlah & Ket \\
\hline & Warna & 25 & 25 & 24 & 74 & $\mathrm{~B}$ \\
\hline & Kesatuan & 27 & 31 & 27 & 85 & $\mathrm{~B}$ \\
\hline & Nilai Fungsional & 24 & 30 & 29 & 83 & B \\
\hline & \multicolumn{4}{|c|}{ Jumlah } & 242 & \\
\hline & \multicolumn{4}{|c|}{ Rata-Rata } & 81 & B \\
\hline
\end{tabular}

Berdasarkan tabel 9, diperoleh hasil dari penilaian karya 2 dari indikator warna pada tim penilai satu memberi nilai 25 , tim penilai dua memberi nilai 25 dan tim penilai tiga memberi nilai 24 dengan jumlah keseluruhan nilai yaitu 74. Pada indikator penilaian kesatuan dengan tim penilai satu memberi nilai yaitu 27 , tim penilai dua memberi nilai 31 , dan tim penilai tiga memberi nilai 27 dengan jumlah nilai keseluruhan 85. Pada indikator penilaian nilai fungsional dengan tim penilai satu memberi nilai 24 , tim penilai dua memberi nilai 30 dan tim penilai tiga memberi nilai 29 dengan jumlah keseluruhan nilai 83. Dari hasil yang di dapatkan dengan jumlah keseluruhan diperoleh nilai 242 dengan nilai rata-rata 81. 
Pinte Ara \& Azmi, Studi Tentang Pembuatan Lampion Berbahan Limbah Goni Rami Pada Mata Pelajaran Prakarya Siswa Kelas VIII SMP Negeri 2 Takengon T.A 2020/2021

Tabel 10. Hasil Penilaian Karya 3

\begin{tabular}{|c|c|c|c|c|c|c|}
\hline Karya Lampion & Indikator & Penilai & Penilai & Penilai & Jumlah & Ket \\
\hline \multirow{3}{*}{} & Penilaian & $\mathbf{1}$ & $\mathbf{2}$ & $\mathbf{3}$ & & \\
\hline & Warna & 31 & 32 & 24 & 87 & $\mathrm{~A}$ \\
\cline { 2 - 8 } & Kesatuan & 29 & 22 & 22 & 73 & $\mathrm{~B}$ \\
\cline { 2 - 7 } & Nilai Fungsional & 29 & 28 & 22 & 79 & $\mathrm{~B}$ \\
\cline { 2 - 7 } & \multicolumn{5}{|c}{ Jumlah } \\
\cline { 2 - 7 } & \multicolumn{3}{|c|}{ Rata-Rata } & $\mathbf{8 0}$ & B \\
\hline
\end{tabular}

Berdasarkan tabel 10, diperoleh hasil dari penilaian karya 3 dari indikator warna pada tim penilai satu memberi nilai 31, tim penilai dua memberi nilai 32 dan tim penilai tiga memberi nilai 24 dengan jumlah keseluruhan nilai yaitu 87. Pada indikator penilaian kesatuan dengan tim penilai satu memberi nilai yaitu 29 , tim penilai dua memberi nilai 22 , dan tim penilai tiga memberi nilai 22 dengan jumlah nilai keseluruhan 73. Pada indikator penilaian nilai fungsional dengan tim penilai satu memberi nilai 29 , tim penilai dua memberi nilai 28 dan tim penilai tiga memberi nilai 22 dengan jumlah keseluruhan nilai 79. Dari hasil yang di dapatkan dengan jumlah keseluruhan diperoleh nilai 239 dengan nilai rata-rata 80.

Tabel 11. Hasil Penilaian Karya 4

\begin{tabular}{|c|c|c|c|c|c|c|}
\hline Karya Lampion & $\begin{array}{l}\text { Indikator } \\
\text { Penilaian } \\
\end{array}$ & $\begin{array}{c}\text { Penilai } \\
1 \\
\end{array}$ & $\begin{array}{c}\text { Penilai } \\
2\end{array}$ & $\begin{array}{c}\text { Penilai } \\
3 \\
\end{array}$ & Jumlah & Ket \\
\hline & Warna & 29 & 25 & 24 & 78 & $\mathrm{~B}$ \\
\hline & Kesatuan & 32 & 28 & 27 & 87 & $\mathrm{~A}$ \\
\hline & Nilai Fungsional & 27 & 25 & 28 & 80 & $\mathrm{~B}$ \\
\hline & \multicolumn{4}{|c|}{ Jumlah } & 247 & \\
\hline & \multicolumn{4}{|c|}{ Rata-Rata } & 82 & B \\
\hline
\end{tabular}

Berdasarkan tabel 10, diperoleh hasil dari penilaian karya 4 dari indikator warna pada tim penilai satu memberi nilai 29 , tim penilai dua memberi nilai 25 dan tim penilai tiga memberi nilai 24 dengan jumlah keseluruhan nilai yaitu 78. Pada indikator penilaian kesatuan dengan tim penilai satu memberi nilai yaitu 32 , tim penilai dua memberi nilai 28 , dan tim penilai tiga memberi nilai 27 dengan jumlah nilai keseluruhan 87. Pada indikator penilaian nilai fungsional dengan tim penilai satu memberi nilai 27 , tim penilai dua memberi nilai 25 dan tim penilai tiga memberi nilai 28 dengan jumlah keseluruhan nilai 80. Dari hasil yang di dapatkan dengan jumlah keseluruhan diperoleh nilai 247 dengan nilai rata-rata 82.

Tabel 12. Hasil Penilaian Karya 5

\begin{tabular}{|c|c|c|c|c|c|c|}
\hline Karya Lampion & $\begin{array}{l}\text { Indikator } \\
\text { Penilaian }\end{array}$ & $\begin{array}{c}\text { Penilai } \\
1\end{array}$ & $\begin{array}{c}\text { Penilai } \\
2\end{array}$ & $\begin{array}{c}\text { Penilai } \\
\mathbf{3} \\
\end{array}$ & Jumlah & Ket \\
\hline & Warna & 29 & 28 & 30 & 87 & $\mathrm{~B}$ \\
\hline & Kesatuan & 35 & 26 & 31 & 92 & $\mathrm{~A}$ \\
\hline & Nilai Fungsional & 25 & 25 & 25 & 75 & $\mathrm{~B}$ \\
\hline & \multicolumn{4}{|c|}{ Jumlah } & 254 & \\
\hline & \multicolumn{4}{|c|}{ Rata-Rata } & 85 & B \\
\hline
\end{tabular}

Berdasarkan tabel 12, diperoleh hasil dari penilaian karya 5 dari indikator warna pada tim penilai satu memberi nilai 29 , tim penilai dua memberi nilai 28 dan tim penilai tiga memberi nilai 30 dengan jumlah keseluruhan nilai yaitu 87. Pada indikator penilaian kesatuan dengan tim penilai satu memberi nilai yaitu 35 , tim penilai dua memberi nilai 26 , dan tim penilai tiga memberi nilai 31 dengan jumlah nilai keseluruhan 92. Pada indikator penilaian nilai fungsional dengan tim penilai satu memberi nilai 25 , tim penilai dua memberi nilai 25 dan tim penilai tiga memberi nilai 
25 dengan jumlah keseluruhan nilai 75. Dari hasil yang di dapatkan dengan jumlah keseluruhan diperoleh nilai 254 dengan nilai rata-rata 85.

\section{SIMPULAN}

Membuat karya kerajinan lampion dengan bahan Limbah goni rami membuat seluruh siswa tidak berpatokan pada bahan-bahan baru (konvensional). berdasarkan indikator Warna, Kesatuan dan Nilai fungsional, ada beberapa karya pada indikator Warna yang harus di perbaiki yaitu visualisasi warna kurang tampak rapi dan kurang tampak serasi dengan bentuk keseluruhannya. Pada indikator kesatuan susunansusuan penempelan tali rami yang terlalu rapat atau jarang sehingga tidak menghasilkan kekokohan karya yang tidak tepat sedangkan pada indikator nilai fungsional karya yang di buat kurang dapat dijadikan lampu tidur atau hias dikarenakan sebagian karya tidak terdapat tempat untuk meletakkan lampu di dalam karya tersebut.

\section{DAFTAR PUSTAKA}

Arikunto, S. (2010). Prosedur Penelitian Suatu Pendekatan Praktek. Jakarta: Rineka Cipta.

Bahari. (2017). Kritik Seni. Yogyakarta: Pustaka Pelajar.

Brikolase. 9(1): 13.

Dharsono. (2017). Seni Rupa Modern. Bandung: Rekayasa Sains

Kota Bandar Lampung tahun 2016, Skripsi. Universitas Negeri Medan.

Luwin, A. (2019). Jenis-Jenis Lampion. Diunduh di https://liwunfamily.com/2019/01/24/pahamilimajenis-lampion-imlek berdasarkan -bentuk-dan-bahan/ tanggal 07 Februari 2020.

Menggunakan Bahan Bekas di Kelompok B2 TK Papahan 03 Karanganyar Tahun Ajaran 2015/ 2016. Solo: Universitas Sebelas Maret.

Rinaldy, S. (2021). Studi Bentuk Kerajinan Bahan Karung Goni Karya Sukirno Di Bengkel Keramas Medan

Sanjaya, O. (2016). Fungsi dan Makna Penyambutan Hari Raya Imlek Pada Masyarakat Etnis Tionghoa Di

Sembiring, D. (2014). Wawasan Seni. Medan: Unimed Press.

Sinaga, D., \& Triyanto, R. (2020). Tinjauan Ilustrasi Cover Novel Harry Potter Edisi Indonesia Karya Nicolas Fiber Ditinjau Dari Elemen Visual. Journal of Education, Humaniora and Social Sciences (JEHSS), 3(1), 265-272. doi:https://doi.org/10.34007/jehss.v3i1.292

Sudjana, Atmojo \& Atika. (2016). Peningkatan Kemampuan Motorik Halus Melalui Kegiatan Prakarya

Sugito, Chairani \& Ibrahim. (2018). Metode Penelitian Pendidikan. Medan: Unimed Press.

Sugiyono. (2011). Metode Penelitian Kuantitatif Kualitatif. Dan R\&D. Bandung: Alfabeta.

Sunggal Kelurahan Tanjung Rejo, Skripsi. Universitas Negeri Medan.

Susanto. (2002). Diksi Rupa. Yogyakarta: Kanisius

Syamsiar, I. (2017). Studi Penciptaan lampion Rotan Loro Blonyo Sebagai Elemen Estetik Interior.

Syamsiar, S. (2016). Lampion Rotan Loro Blonyo Sebagai Elemen Estetik Interior. Surakarta: ISI.

Tanjung, D., \& Munte, S. (2020). Pelatihan Pembuatan Bata Ringan Kepada Home Industri Batu Bata Konvensional Guna Mendukung Program Pemerintah 1 Juta Rumah Bersubsidi. Journal of Education, Humaniora and Social Sciences (JEHSS), 2(3), 578-582. doi:https://doi.org/10.34007/jehss.v2i3.116

Tjoa, S. (2011). Tahun Baru Imlek dan Lampion. Diunduh di http://sosbud.kompasiana.com/2011/01/16/tahun-baru-imlek-dan-lampion333794 tanggal 07 Februari 2020.

Togarma, M. (1998). Metodologi Riset Seni Rupa dan Desain. Jakarta: Universitas Trisakti.

Utami, A., Soeprayogi, H., \& Azis, A. (2020). Pembuatan Kerajinan Bunga Berbahan Kulit Jagung Ditinjau dari Prinsip-prinsip Seni Rupa dan Kerajinan. Journal of Education, Humaniora and Social Sciences (JEHSS), 3(1), 260-264. doi:https://doi.org/10.34007/jehss.v3i1.282

Wong. (1986). Beberapa Asas Merancang Dwitrimatra. Bandung: ITB. 